\title{
Variability in Response of Groundnut (Arachis hypogaea L.) Genotypes to Moisture Stress and Stress Release
}

\author{
V. Sunitha*, M. Vanaja, P. Sowmya, S. K. Abdul Razak , G. Vijay Kumar, Y. Anitha, N. Jyothi Lakshmi \\ Central Research Institute for Dryland Agriculture, Santoshnagar, Hyderabad (500 059), India
}

\section{Article History}

Manuscript No. 1081b

Received in $18^{\text {th }}$ November, 2014

Received in revised form $8^{\text {th }}$ March, 2015

Accepted in final form $28^{\text {th }}$ March, 2015

\section{Correspondence to}

"E-mail: sunithavaidya@gmail.com

\section{Keywords}

Groundnut, moisture stress, stress recovery, growth, biochemical, yield

\begin{abstract}
Groundnut (Arachis hypogaea L.) is an important oilseed cash crop and an erratic rainfall with prolonged dry spells during critical pheno-phases of reproductive stages affects its yield. A field trial was carried out with groundnut genotypes- JL24, ICGV 91114, Narayani, Abhaya, Dharani and Greeshma to study the variability in morphological, biochemical and yield traits to moisture stress at flowering stage. Significant reduction in growth and yield components of all the selected groundnut genotypes was observed due to moisture stress. ANOVA for pod weight, seed weight, 100 seed weight, harvest index, total biomass were found to be highly significant $(p<0.01)$ for genotypes, moisture levels and their interactions. Impact of moisture stress on plant height, leaf area, leaf and shoot biomass was lowest in Dharani and osmoprotectant- proline and activity of antioxidant enzymes- SOD and POD were higher in Dharani. The yield performance of Narayani, Abhaya, Dharani were similar as well as superior under control condition where as under moisture stress conditions Dharani recorded highest seed yield, HI with lowest reduction in seed number and 100 seed weight. Under control conditions seed yield had significant positive correlation with pod number, pod weight and seed number whereas under moisture stress conditions with SOD, POD, leaf area, leaf dry weight, pod weight, seed number, 100 seed weight and shelling \%. The groundnut genotype Dharani performed best under both control and moisture stress conditions as its high antioxidative enzyme activity and proline content might have been ameliorated the ill effects of moisture stress.
\end{abstract}

\section{Introduction}

Agriculture production generally influenced by extreme climatic events, of which drought (moisture stress) is one of the most important abiotic stresses which influences livelihood of people who depended directly or indirectly on agriculture. In countries like India moisture stress is a recurring chronic problem which has a sizeable proportion of area falling in arid and semi-arid tropics. Two thirds of India's agricultural land is vulnerable to moisture stress of various intensities, and the probability of occurrence of a moisture stress is over $35 \%$ (Bhandari et al., 2007). The yield of pulse crops can be severely affected due to moisture stress at reproductive stages and even stress release will not have a significant impact on yield improvement (Baroowa et al., 2012). The performance of crop in terms of growth, biomass accumulation, and yield depends on crop's ability to withstand, acclimate, or recover from the stress and both stress tolerance and recovery often involve a complex network of biochemical processes (Prasad and Staggenborg, 2008). The impacts on these various processes and traits depend on the intensity, rate of increase, duration of stress, stage of development and genotype (Puangbut et al., 2009; Prasad and Staggenborg, 2008).

Groundnut (Arachis hypogaea L.) is an important oilseed cash crop for all tropical and sub-tropical regions. Among different abiotic stresses, drought (moisture stress) is one of the most important factors, which can limit the production of groundnut (Shinde et al., 2010a). Due to erratic rain fall and frequent drought during the crop growth period groundnut yields are generally low and unstable under rain-dependent conditions (Reddy et al., 2013; John et al., 2011). Adequate moisture is essential during key stages of groundnut crop like flowering and pod filling and even short periods of moisture stress during these stages can cause significant loss in yield of this crop (Shinde et al., 2010a). Since moisture stress brings 
about changes in growth rate, biomass, (Rajababu et al., 2011) biochemical parameters such as proline and antioxidant enzymes (Sharada and Naik, 2011) and yield (Puangbut et al., 2009) in groundnut, a thorough knowledge during stress and recovery of these traits becomes imperative to identify tolerant genotype with high yield. So the present study was undertaken to assess the effect of moisture stress on growth, accumulation of biomass, biochemical changes during stress as well as stress recovery and yield of different genotypes to identify those groundnut genotype which have the ability to tolerate water stress.

\section{Materials and Methods}

A field experiment was conducted with six groundnut genotypes JL-24, ICGV 91114, Narayani, Abhaya, Dharani at research farm of Central Research Institute for Dryland Agriculture (CRIDA), Hyderabad, Telangana, India, located between $17.20^{\circ} \mathrm{N}$ latitude and $78.30^{\circ} \mathrm{E}$ longitude and at an elevation of $515 \mathrm{~m}$ above msl during summer season (February -May) 2014. The pods of these genotypes were obtained from ICRISAT, Hyderabad (JL-24 and ICGV 91114) and Regional Research Centre, Tirupathi (Narayani, Abhaya, Dharani) and dehulled just before sowing. Three field replications were maintained for each treatment i.e. 1) Control (CN) treatment in which plants were irrigated at regular intervals in order to maintain stress free condition, and 2) Moisture stress (MS) treatment was imposed at first flush of flowering stage by withholding irrigation for 12 days till wilting symptoms were visible and then stress was relieved to assess the recovery. The average temperature was $26.2{ }^{\circ} \mathrm{C}$, minimum maximum temperature recorded during crop growth period was $13.6^{\circ} \mathrm{C}$ and $41.7^{\circ} \mathrm{C}$ (Figure 1). Recommended agronomic practices and plant protection measures were followed, except for the irrigation schedules, when soil moisture stress was imposed by withholding irrigation. Five plants from each treatment were carefully removed in each replication of all the genotypes and growth parameters such as leaf area, plant height, biomass parameters leaf dry weight, stem dry weight were recorded.

Biochemical parameters such as proline, superoxide dismutase (SOD), peroxidase (POD) were assayed in leaves extractions during stress as well as stress recovery stage. Proline was estimated by acid-ninhydrin method (Bates et al., 1973). SOD and POD were assayed according to method of Dhindsa et al. (1981), and Castillo et al. (1984) respectively. Soluble protein content in the enzyme extract was determined using bovine serum albumin as standard (Lowry et al., 1951).

At harvest the observations on all the morphological and biomass parameters along with yield parameters such as number of pods, seeds, pod weight, seed weight and 100 seed weights were recorded in both $\mathrm{CN}$ and MS treatments. Specific leaf weight (SLW), shelling \%, harvest index (HI) were calculated from the recorded values. Vegetative biomass was calculated as the total of dry root, leaf and stem weight and pod yield as reproductive biomass, total biomass consisted of vegetative biomass and reproductive biomass. The biomass partitioning, calculated as (root/shoot/leaf/pod) dry weight/ total dry weight of the plant and expressed as percentage.

The data was statistically analyzed using a three-way analysis of variance (ANOVA) for growth, biochemical parameters to test the significance of genotypes, growth stages, moisture levels and their interactions and two-way for yield parameters to test the significance of genotypes, moisture levels and interactions. Correlation coefficient analysis was performed to study the interrelationship between different traits.

\section{Results and Discussion}

The mean performance and ANOVA for growth, biomass, biochemical and yield parameters were presented in Tables $1-4$.

\subsection{Effect of moisture stress on growth and dry matter production}

Moisture stress reduced all growth parameters such as plant height, leaf area and dry weight of leaf and stem during stress and recovery stage in selected groundnut genotypes compared to control plants (Table 1). Plant height was highly significant $(p<0.01)$ for genotypes, moisture levels, growth stages, growth stages $\times$ moisture levels, genotypes $\times$ growth stages, genotypes $\times$ moisture levels and significant $(p<0.05)$ for genotypes $\times$ growth stages $\times$ moisture levels (Table 2 ). Reduction of plant height with stress condition was lower in Dharani $(2.5 \%)$ whereas high in JL-24 (28.7\%) and at recovery stage in Abhaya (9\%) and reduction was lower for ICGV 91114 $(12 \%)$ and higher for JL-24 (38\%) (Figure 2). At recovery stage, plant height of all genotypes did not recover with that of respective controls and genotype Dharani maintained higher plant height at control $\left(18.4 \mathrm{~cm} \mathrm{plant}^{-1}\right)$ as well as stress release $\left(14 \mathrm{~cm} \mathrm{plant}^{-1}\right)$ conditions. Our results are in line with earlier reports of decreased shoot growth in groundnut due to moistures stress (Madhusudhan and Sudhakar, 2014a). Baroowa et al. (2012) also reported that plant height reduced in black gram and green gram genotypes due to moisture stress and their recovery not up to the control in these two crops. Moisture stress decreases rapid cell division, elongation and enlargement due to low turgor, which might have ultimately lead to the reduction in plant height (Sanker et al., 2007), which will avoid excessive dehydration in groundnut and is an adaptation by plants (Ratnakumar and Vadez, 2011) under moisture stress conditions. 


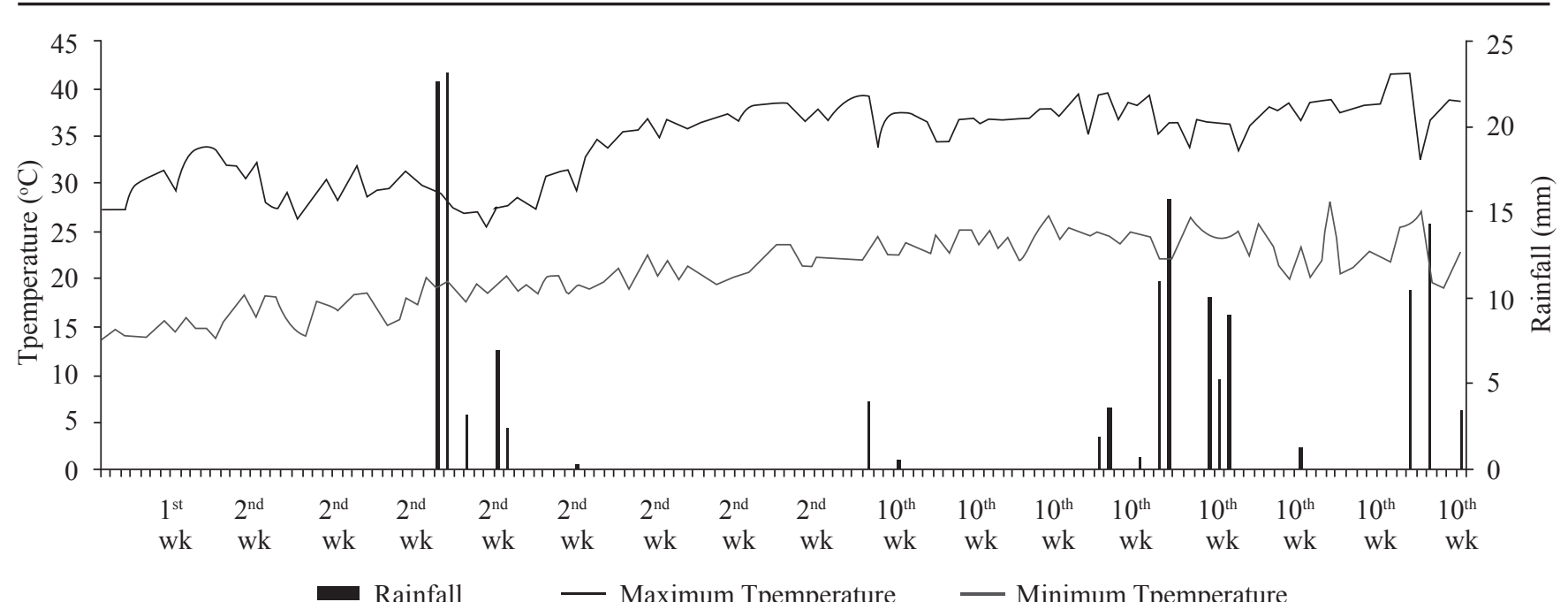

Figure 1: Mean, minimum and maximum temperature and rainfall recorded during crop growth period

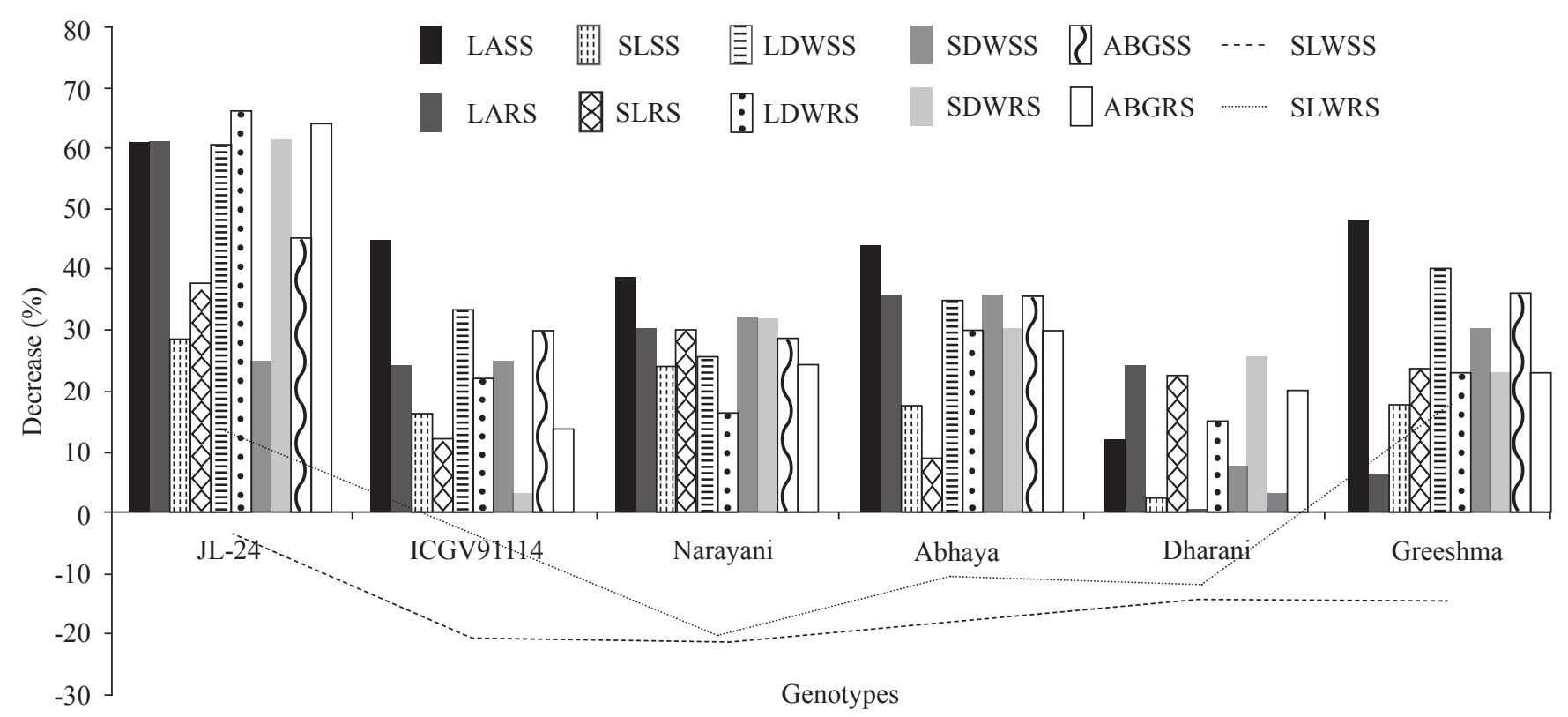

Figure 2: \% decrease of growth parameters during stress stage (SS) and recovery stage (RS) over control due to moisture stress in groundnut genotypes

Leaf area was significantly reduced due to moisture stress. It was highly significant $(p<0.01)$ for genotypes, growth stages, moisture levels and their interactions. The genotype Dharani recorded lowest reduction in leaf area during stress. The higher leaf area was recorded in genotypes JL-24 (708.3 $\mathrm{cm}^{2}$ plant $\left.^{-1}\right)$ and Greeshma $\left(681 \mathrm{~cm}^{2}\right.$ plant $\left.{ }^{-1}\right)$ in control plants, however the reduction in leaf area was highest in JL-24 (60.6\%) (Figure 2) with stress and it could not recovered even after stress release whereas with genotype Greeshma though the reduction in leaf area was high with stress it could recover efficiently. Madhusudan and Sudhakar, (2014a) also reported that moisture stress reduced leaf area of groundnut genotypes and the magnitude of reduction was relatively more in JL-24.
This reduced leaf area may be because of mitotic sensitivity and decrease of leaf expansion under moisture stress conditions.

The yield integrates many of the plant morphological processes in a complex way and reduced leaf area decreases carbon assimilation (Reddy et al., 2003) and eventually the yield of crop.

ANOVA revealed that leaf dry weight (LDW), shoot dry weight (SDW) and above ground biomass (AGB) were highly significant $(p<0.01)$ for genotypes, growth stages, moisture levels and their interactions. Leaf dry weight decreased significantly due to moisture stress at both stress and recovery stages. Lowest reduction in LDW was observed with Dharani $(0.4 \%$ and $15 \%)$ during stress and stress release stages. Under 
Table 1: Mean performance of growth, biomass and biochemical parameters during moisture stress and recovery stages in groundnut genotype

\begin{tabular}{|c|c|c|c|c|c|c|c|c|c|c|c|c|c|c|c|c|c|c|c|}
\hline \multirow[b]{3}{*}{$\begin{array}{l}\text { Geno- } \\
\text { types }\end{array}$} & \multirow[b]{3}{*}{$\begin{array}{l}\text { Treat- } \\
\text { ment }\end{array}$} & \multicolumn{18}{|c|}{ Parameter } \\
\hline & & \multicolumn{2}{|c|}{ Pl.Ht } & \multicolumn{2}{|c|}{ LA } & \multicolumn{2}{|c|}{ LDW } & \multicolumn{2}{|c|}{ SDW } & \multicolumn{2}{|c|}{ SLW } & \multicolumn{2}{|c|}{ AGB } & \multicolumn{2}{|c|}{ Proline } & \multicolumn{2}{|c|}{ SOD } & \multicolumn{2}{|c|}{ POD } \\
\hline & & I & II & I & II & I & II & I & II & I & II & I & II & I & II & I & II & I & II \\
\hline \multirow[t]{2}{*}{ JL-24 } & $\mathrm{CN}$ & 10.9 & 14.9 & 708 & 1691 & 4.7 & 12.5 & 3.6 & 10.1 & 6.7 & 7.4 & 8.3 & 22.6 & 0.11 & 0.10 & 11.7 & 11.7 & 19.7 & 20.7 \\
\hline & Ms & 7.8 & 9.2 & 269 & 659 & 1.9 & 4.3 & 2.7 & 3.8 & 6.9 & 6.5 & 4.6 & 8.1 & 0.54 & 0.22 & 14.7 & 12.3 & 22.4 & 21.4 \\
\hline ICG & $\mathrm{Cl}$ & 7.2 & 13.5 & 505 & 1287 & 3.5 & 9.1 & 2.6 & 6.6 & 7 & 7.1 & 6.2 & 15.7 & 0.16 & 0.14 & 10.8 & 11.0 & 15.4 & 15.4 \\
\hline 91114 & MS & 6 & 11.8 & 278 & 976 & 2.3 & 7.1 & 2 & 6.4 & 8.4 & 7.3 & 4.3 & 13.5 & 0.64 & 0.28 & 19.0 & 14.7 & 17.5 & 15.5 \\
\hline \multirow{2}{*}{$\begin{array}{l}\text { Nara- } \\
\text { yani }\end{array}$} & C & 7.9 & 15.1 & 462 & 1320 & 2.9 & 8.3 & 2.6 & 8.5 & 6.3 & 6.7 & 5.5 & 16.8 & 0.13 & 0.12 & 10.7 & 12.0 & 19.4 & 18.4 \\
\hline & $\mathrm{MS}$ & 6 & 10.6 & 282 & 918 & 2.1 & 6.9 & 1.8 & 5.8 & 7.6 & 7.5 & 3.9 & 12.7 & 0.88 & 0.23 & 21.9 & 16.5 & 23.5 & 21.5 \\
\hline \multirow{2}{*}{$\begin{array}{l}\text { Ab- } \\
\text { haya }\end{array}$} & $\mathrm{C}$ & 7.9 & 15.5 & 686 & 1945 & 4.8 & 11.6 & 4.1 & 8.7 & 7 & 5.9 & 9 & 20.3 & 0.14 & 0.11 & 10.6 & 13.0 & 17.8 & 18.8 \\
\hline & MS & 6.5 & 14.1 & 382 & 1244 & 3.1 & 8.1 & 2.7 & 6.1 & 8.2 & 6.6 & 5.8 & 14.2 & 1.05 & 0.21 & 22.2 & 14.2 & 24.6 & 20.6 \\
\hline \multirow{2}{*}{$\begin{array}{l}\text { Dha- } \\
\text { rani }\end{array}$} & C & 7.9 & 18.4 & 578 & 1684 & 4.3 & 12.6 & 2.9 & 11.5 & 7.5 & 7.5 & 7.2 & 24.1 & 0.10 & 0.11 & 12.1 & 14.2 & 17.5 & 19.5 \\
\hline & $\mathrm{N}$ & 7.7 & 14.2 & 507 & 1279 & 4.3 & 10.7 & 2.7 & 8.5 & 8.5 & 8.4 & 7 & 19.3 & 1.11 & 0.20 & 24.6 & 15.3 & 26.3 & 20.3 \\
\hline \multirow{2}{*}{$\begin{array}{l}\text { Greesh- } \\
\text { ma }\end{array}$} & $\mathrm{CN}$ & 10 & 17.1 & 681 & 953 & 5 & 8.6 & 3.7 & 7.7 & 7.4 & 9.1 & 8.7 & 16.3 & 0.14 & 0.13 & 13.2 & 12.2 & 15.7 & 16.7 \\
\hline & Ms & 8.2 & 13 & 353 & 891 & 3 & 6.6 & 2.6 & 5.9 & 8.5 & 7.4 & 5.6 & 12.5 & 1.01 & 0.27 & 21.1 & 17.3 & 17.7 & 16.2 \\
\hline \multirow[t]{2}{*}{ SED } & $\mathrm{CN}$ & 0.3 & 0.66 & 35 & 59.5 & 0.38 & 0.6 & 0.34 & 0.9 & 0.57 & 0.23 & 0.7 & 1.3 & 0.006 & 0.013 & 1.34 & 1.23 & 0.67 & 0.59 \\
\hline & MS & 0.3 & 0.9 & 18 & 73.7 & 0.2 & 0.8 & 0.2 & 0.8 & 0.78 & 0.6 & 0.2 & 1.5 & 0.016 & 0.01 & 0.53 & 1.8 & 0.9 & 1.2 \\
\hline \multirow[t]{2}{*}{$\mathrm{CD}^{*}$} & $\mathrm{CN}$ & 0.8 & 1.5 & 78 & 132 & 0.9 & 1.3 & 0.8 & 2.1 & 1.3 & 0.5 & 1.5 & 2.9 & 0.013 & 0.005 & 2.9 & 2.7 & 1.5 & 1.3 \\
\hline & MS & 0.7 & 2 & 40.2 & 164 & 0.5 & 1.8 & 0.5 & 1.9 & 1.7 & 1.3 & 0.5 & 3.3 & 0.035 & 0.022 & 1.2 & 2.6 & 1.9 & 2.6 \\
\hline \multirow[t]{2}{*}{$\mathrm{CD}^{* *}$} & $\mathrm{CN}$ & 1.1 & 2.1 & 111 & 188 & 1.2 & 1.9 & 1 & 2.9 & 1.8 & 0.7 & 2 & 4.1 & 0.018 & 0.003 & 4.3 & 3.8 & 2.1 & 1.9 \\
\hline & MS & 1 & 2.9 & 57 & 233 & 0.7 & 2.6 & 0.7 & 2.7 & 2.5 & 1.8 & 0.7 & 4.8 & 0.05 & 0.031 & 1.7 & 3.7 & 2.8 & 3.7 \\
\hline
\end{tabular}

CN I- Control for moisture stress stage; CN II- Control for recovery stage; MS I-Moisture stress stage; MS II- Moisture stress recovery stage

Table 2: ANOVA for growth and biochemical parameters at two growth stages-during stress and recovery in groundnut genotypes

\begin{tabular}{lcccccccccc}
\hline Source of & \multicolumn{10}{c}{ Mean sum squares } \\
\cline { 2 - 11 } variation & D.F & Pl.Ht & LA & LDW & SDW & SLW & AGB & Proline & SOD & POD \\
\hline $\mathrm{G}$ & 1 & $12.9^{* *}$ & $259311^{* *}$ & $13.7^{* *}$ & $6.3^{* *}$ & $3.7^{* *}$ & $37.4^{* *}$ & $0.038^{* *}$ & $21.1^{* *}$ & $28.2^{* *}$ \\
$\mathrm{GS}$ & 1 & $677.1^{* *}$ & $10472603^{* *}$ & $518.4^{* *}$ & $387.3^{* *}$ & $1.2 \mathrm{NS}$ & $1798^{* *}$ & $1.882^{* *}$ & $73^{* *}$ & $22^{*}$ \\
$\mathrm{M}$ & 5 & $121.7^{* *}$ & $2489632^{* *}$ & $94.3^{* *}$ & $59.0^{* *}$ & $5.9^{* *}$ & $302^{* *}$ & $3.33^{* *}$ & $613^{* *}$ & $107^{* *}$ \\
$\mathrm{G} \times \mathrm{GS}$ & 1 & $11.9^{* *}$ & $152510^{* *}$ & $4.5^{* *}$ & $5.4^{* *}$ & $1.0 \mathrm{NS}$ & $18^{* *}$ & $0.04^{* *}$ & $2.73 \mathrm{NS}$ & $14.5^{*}$ \\
$\mathrm{GS} \times \mathrm{M}$ & 5 & $17.6^{* *}$ & $232855^{* *}$ & $13.5^{* *}$ & $17.4^{* *}$ & $4.4^{* *}$ & $62^{* *}$ & $1.7^{* *}$ & $148^{* *}$ & $70.4^{*}$ \\
$\mathrm{G} \times \mathrm{M}$ & 5 & $4.0^{* *}$ & $129704^{* *}$ & $8.9^{* *}$ & $3.1^{* *}$ & $1.3^{*}$ & $20.7^{* *}$ & $0.039^{* *}$ & $7.6^{* *}$ & $12.5^{*}$ \\
$\mathrm{G} \times \mathrm{GS} \times \mathrm{M}$ & 5 & $1.6^{*}$ & $65751^{* *}$ & $2.7^{* *}$ & $2.9^{* *}$ & $0.78 \mathrm{NS}$ & $10.8^{* *}$ & $0.046^{* *}$ & $13.7^{* *}$ & $16.9^{* *}$ \\
Error & 46 & 0.61 & 4997 & 0.50 & 0.57 & 0.48 & 1.60 & 0.01 & 1.82 & 4.7 \\
$\mathrm{CV}(\%)$ & - & 7.2 & 8.26 & 11.5 & 14.7 & 9.5 & 11.2 & 4.32 & 9.1 & 11.3 \\
\hline
\end{tabular}

"significant at $p<0.05 ;{ }^{* *}$ significant at $p<0.01$; G-Genotypes; GS: Growth Stages; M: Moisture levels; LA: Leaf Area $\left(\mathrm{cm}^{2}\right.$ plant $\left.\mathrm{t}^{-1}\right)$; Pl. Ht: Plant Height (cm plant $\left.{ }^{-1}\right)$; LDW: Leaf Dry Weight (g plant $\left.{ }^{-1}\right)$; SDW: Stem Dry Weight $\left(\right.$ g plant $\left.^{-1}\right)$; SLW: Specific Leaf Weight $\left(\mathrm{mg} \mathrm{cm}^{2}\right)$; AGB: Above ground Biomass $\left(\mathrm{g} \mathrm{plant}^{-1}\right)$; Proline $\left(\mathrm{mg} \mathrm{g}^{-1}\right.$ fresh weight); SOD: Superoxide dismutase (U mg protein minute ${ }^{-1}$ ); POD: Peroxidase (U mg protein minute ${ }^{-1}$ )

control conditions higher LDW was recorded with JL-24 and Dharani (12 $\mathrm{cm}$ plant $\left.^{-1}\right)$, however after stress release Dharani $\left(10.71 \mathrm{~cm} \mathrm{plant}^{-1}\right)$ recovered well whereas recovery was poor with JL-24 (61\% and 66\%). In the present investigation, SLW was highly significant $(p<0.01)$ for genotypes, moisture levels, growth stages $\times$ moisture levels. Under moistures stress, there was an improvement in SLW of groundnut genotypes. Specific leaf weight (SLW) was higher in Dharani and lower in JL-24 
at stress and recovery stages. In maize SLW increased under moisture stress (Vanaja et al., 2011) and moisture stress results in fewer and smaller leaves which have smaller and more compact cells and there by greater SLW. Leaf thickness plays an important role in leaf and plant functioning, and relates to a species strategy of resource acquisition and use.

Moisture stress reduced SDW significantly and it ranged from to $2.6 \mathrm{~g}_{\text {plant }}{ }^{-1}$ (ICGV 91114 and Narayani) to $4.1 \mathrm{~g}$ plant $^{-1}$ (Abhaya) in controls where as with imposition of moisture stress it was $1.8 \mathrm{~g}$ plant $^{-1}$ (Narayani) to $2.7 \mathrm{~g} \mathrm{plant}^{-1}$ (JL-24, Dharani). However, with stress release the recovery varied with genotypes and Dharani and ICGV 91114 recovered maximum and minimum was with JL-24. The selected groundnut genotypes differed in production of AGB and the genotypes Dharani and ICGV 91114 though recorded less reduction and high recovery, their per se values are contrasting as Dharani (7.0 g plant $^{-1}$ and $24.1 \mathrm{~g} \mathrm{plant}^{-1}$ ) with higher AGB and ICGV 91114 (4.3 g plant $^{-1}$ and 13.5 g plant $\left.^{-1}\right)$ with lowest. Similar observations of biomass responses with moisture stress were reported in groundnut genotypes (Madhusudan and Sudhakar, 2014a; 2014b).

\subsection{Effect of moisture stress on biochemical parameters}

Increase in the content of proline- an osmoprotectant and activity of antioxidant enzymes such as SOD and POD was recorded under moisture stress conditions in all the genotypes, however their magnitude of response varied (Table 1). Proline (Pr) content was highly significant $(p<0.01)$ for genotypes, growth stages, moisture levels and their interactions. The genotypes Dharani and Abhaya registered higher proline content with higher increment under moisture stress and it reduced to control levels at recovery stage in these genotypes. As accumulation of proline helps in osmotic balance during stress conditions, so the genotypes Dharani and Abhaya with higher proline content under moisture stress conditions are expected to have better stress tolerance capacity. Similar increase in proline content under stress condition and reduced to control levels after stress release was reported in pearl millet (Vijaya lakshmi et al., 2012).

SOD was highly significant $(p<0.01)$ for genotypes, growth stages, moisture levels, growth stages $\times$ moisture levels, genotypes $\times$ moisture levels and genotypes $\times$ growth stages $\times$ moisture levels. Increase in the activity of SOD was high during moisture stress conditions in genotypes Dharani, Abhaya, Narayani whereas at recovery decreased SOD to control levels was observed in Dharani and Abhaya. The activity of POD was highly significant $(p<0.01)$ for genotypes, moisture levels, growth stages $\times$ moisture levels, and genotypes $\times$ growth stages $\times$ moisture levels and significant $(p<0.05)$ for growth stages, genotypes $\times$ moisture levels, growth stages $\times$ moisture levels. POD activity increased significantly at moisture stress conditions and Dharani and Abhaya recorded higher POD with higher increment whereas POD decreased to control levels at recovery stage in Dharani indicating its excellent recovery. Antioxidant enzymes SOD and POD play an important role in moisture tolerance capacity in plants. Bhardwaj and Yadav, (2012) reported that increase of antioxidant enzymes- SOD and POD under moisture stress conditions in horsegram and was more in drought tolerant genotypes as they play an important role in defense system against moisture stress.

\subsection{Effect of moisture stress on yield and yield attributing parameters}

Moisture stress at flowering stage significantly reduced yield components of all the selected groundnut genotypes (Table 3-4). Among the six genotypes, the yield performance of Narayani, Abhaya, Dharani were found to be similar as well as superior under irrigated condition, however they differed with imposition of moisture stress. The two-way ANOVA revealed that pod number was non-significant for moisture levels however highly significant $(p<0.01)$ for genotypes and interaction of genotypes $\times$ moisture levels. Moisture stress decreased pod number except in JL-24 and ICGV 91114 which indicates that in these two genotypes pollination and fertilization was not influenced with stress. Higher pod number was recorded in Narayani (62.8 plant $\left.^{-1}\right)$ and Dharani (59.3 plant $^{-1}$ ) under control conditions, while in ICGV 91114 (57 plant $^{-1}$ ) and Dharani (52.2 plant $\left.^{-1}\right)$ under stress. Raja Babu et al. (2011) reported that moisture stress drastically reduced number of mature pods of groundnut genotypes and JL-24 was highly affected. Pod weight was highly significant $(p<0.01)$ for genotypes, moisture levels and their interaction. Higher pod weight was recorded by Narayani, Abhaya and Dharani $\left(40 \mathrm{~g} \mathrm{plant}^{-1}\right)$ at irrigated controls whereas with imposition of moisture stress, highest pod weight was recorded by Dharani $\left(30.9\right.$ g plant $\left.^{-1}\right)$ with lowest impact of moisture stress. Moisture stress has less effect on pod yield of ICGV 91114 however the per se yield of this genotype was lowest as compared to high yielding genotypes Dharani, Abhaya and Narayani. Shinde et al. (2010b) also reported that pod weight decreased due to moisture stress and TAG-24 showed less reduction (46.25\%) than TG-26 (72.59\%) over control. Seed number reduced due to moisture stress in all genotypes and it was highly significant $(p<0.01)$ for genotypes, moistures levels and significant $(p<0.05)$ for genotypes $\times$ moisture levels. Seed number ranged from 59-92 plants $^{-1}$ in control plants where as 50-70 plants ${ }^{-1}$ under moisture stress. The genotype Dharani recorded highest seed number at moisture stress treatment. Moistures stress at flowering stage in bambara groundnut reduced seed 


\begin{tabular}{lcccccccc}
\hline \multicolumn{7}{l}{ Table 3: Yield traits at control and } & moisture stress conditions in groundnut genotypes \\
\hline \multicolumn{7}{c}{ Parameters } \\
\hline Genotypes & Treatment & PN & PW & SN & SW & 100 SW & HI & SH \\
\hline JL-24 & Control & 46.7 & 31.5 & 67.0 & 20.2 & 30.0 & 27.0 & 64.1 \\
& Moisture stress & 54.2 & 21.7 & 50.3 & 12.5 & 24.7 & 18.7 & 57.6 \\
\multirow{7}{*}{ ICGV91114 } & Decrease (\%) & -16.1 & 31.0 & 24.9 & 38.1 & 17.8 & 30.9 & 10.2 \\
& Control & 43.5 & 23.5 & 62.7 & 14.7 & 24.4 & 25.8 & 62.5 \\
& Moisture stress & 57.5 & 22.1 & 58.7 & 13.8 & 21.7 & 18.0 & 62.2 \\
Narayani & Decrease (\%) & -32.2 & 5.7 & 6.4 & 6.1 & 11.2 & 30.1 & 0.4 \\
& Control & 62.8 & 40.9 & 91.0 & 23.6 & 26.6 & 26.0 & 57.8 \\
& Moisture stress & 48.5 & 24.8 & 53.8 & 15.6 & 25.7 & 22.6 & 62.9 \\
Abhaya & Decrease (\%) & 22.8 & 39.4 & 40.8 & 34.1 & 3.4 & 13.4 & -8.8 \\
& Control & 51.8 & 39.9 & 92.8 & 26.6 & 30.8 & 34.4 & 66.6 \\
& Moisture stress & 44.0 & 24.4 & 59.5 & 17.4 & 28.1 & 32.3 & 71.2 \\
Dharani & Decrease (\%) & 15.1 & 38.7 & 35.9 & 34.6 & 8.9 & 6.0 & -6.8 \\
& Control & 59.3 & 39.5 & 92.8 & 29.3 & 31.5 & 38.5 & 74.1 \\
& Moisture stress & 52.2 & 30.9 & 70.2 & 21.8 & 31.0 & 33.9 & 72.7 \\
Greeshma & Decrease (\%) & 12.1 & 21.6 & 24.4 & 25.6 & 1.6 & 11.9 & 2.0 \\
& Control & 39.0 & 28.4 & 59.7 & 19.7 & 31.4 & 37.5 & 69.5 \\
& Moisture stress & 30.0 & 18.3 & 42.5 & 11.1 & 25.0 & 31.4 & 60.7 \\
SED & Decrease (\%) & 23.1 & 35.6 & 28.8 & 43.7 & 20.4 & 16.1 & 12.7 \\
& Control & 4.2 & 2.2 & 9.5 & 1.6 & 1.4 & 0.6 & 2.3 \\
CD* & Moisture stress & 4.0 & 2.4 & 5.4 & 1.5 & 1.1 & 1.6 & 3.4 \\
& Control & 9.3 & 4.9 & 21.2 & 3.6 & 3.0 & 1.4 & 5.0 \\
& Moisture stress & 8.9 & 5.6 & 12.1 & 3.3 & 2.4 & 3.6 & 7.7 \\
& Control & 13.2 & 6.9 & 30.1 & 5.2 & 4.3 & 2.0 & 7.2 \\
& Moisture stress & 12.6 & 7.5 & 17.1 & 4.7 & 3.4 & 5.1 & 11.1 \\
\hline
\end{tabular}

\begin{tabular}{|c|c|c|c|c|c|c|c|c|c|c|c|c|c|c|c|}
\hline \multicolumn{16}{|c|}{ Mean sum of squares } \\
\hline $\begin{array}{l}\text { Source of } \\
\text { variation }\end{array}$ & D.F & $\mathrm{PN}$ & PW & SN & SW & $\begin{array}{l}100 \\
\text { SW }\end{array}$ & $\mathrm{HI}$ & SH & VB & $\mathrm{RB}$ & TB & $\begin{array}{l}\text { Al- } \\
\text { Root }\end{array}$ & $\begin{array}{l}\text { Al- } \\
\text { Leaf }\end{array}$ & $\begin{array}{l}\text { Al- } \\
\text { Stem }\end{array}$ & $\begin{array}{l}\text { Al- } \\
\text { Pod }\end{array}$ \\
\hline $\mathrm{G}$ & 5 & $366^{* *}$ & $167^{* *}$ & $823^{* *}$ & $113^{* *}$ & $86^{* *}$ & $258^{* *}$ & $18 \mathrm{NS}$ & $586^{* *}$ & $158^{* *}$ & $4712^{* *}$ & $0.78^{*}$ & $115^{* *}$ & $79^{* *}$ & $313^{* *}$ \\
\hline M & 1 & $71 \mathrm{NS}$ & $939^{* *}$ & $4290^{* *}$ & $439^{* *}$ & $47^{* *}$ & $250^{* *}$ & $137^{* *}$ & $167^{*}$ & $3109^{* *}$ & $820^{* *}$ & $5^{* *}$ & $588^{* *}$ & $315^{* *}$ & $1956^{* *}$ \\
\hline $\mathrm{G} \times \mathrm{M}$ & 5 & $181^{* *}$ & $43^{* *}$ & $220^{*}$ & $13.9^{* *}$ & $8.2^{*}$ & $9^{* *}$ & $48^{*}$ & $271^{* *}$ & $42^{* *}$ & $521^{* *}$ & $2^{* *}$ & $8^{*}$ & $19^{* *}$ & $21^{* *}$ \\
\hline Error & 22 & 20 & 7.6 & 82.4 & 3 & 2.2 & 2.1 & 14.1 & 22.8 & 4.8 & 39 & 0.29 & 2.3 & 1.9 & 4.5 \\
\hline $\mathrm{CV}(\%)$ & - & 9.2 & 9.6 & 13.6 & 9.2 & 5.4 & 5.1 & 5.8 & 12.5 & 8.9 & 9.9 & 25.9 & 6.1 & 4 & 5.5 \\
\hline
\end{tabular}

${ }^{*}$ significant at $p<0.05 ;{ }^{* *}$ significant at $p<0.01$; PN: Pod Number $\left(\right.$ plant $\left.^{-1}\right)$; PW: Pod Weight $\left(\right.$ g plant $\left.^{-1}\right)$; SN: Seed Number (plant $\left.^{-1}\right)$; SW: Seed Weight (g plant $\left.{ }^{-1}\right) ; 100$ SW: 100 Seed weight (g plant $\left.{ }^{-1}\right)$; HI: Harvest Index; SH: Shelling \%, VB: Vegetative biomass $\left(\mathrm{g}_{\text {plant }}{ }^{-1}\right)$; RB: Reproductive biomass $\left(\mathrm{g} \mathrm{plant}^{-1}\right)$; TB: Total biomass (g plant $\left.{ }^{-1}\right)$; Al-Allocation to.

number significantly and lowest seed number was in summer season (Vurayai et al., 2011). Seed weight reduced under stress conditions and it was highly significant $(p<0.01)$ for genotypes, moisture levels and their interaction. The genotype Dharani recorded higher per se seed weight under control (29 $\left.\mathrm{g}_{\text {plant }}{ }^{-1}\right)$ as well as stress $\left(21.7\right.$ g plant $\left.^{-1}\right)$ conditions whereas lowest values with Greeshma (11 $\left.\mathrm{g} \mathrm{plant}^{-1}\right)$ and JL-24 (12.5 g plant $\left.{ }^{-1}\right)$. Dharani with highest seed yield and ICGV 91114 with low seed yield recorded lowest reduction with moisture stress whereas Greeshma (43.7\%) and JL-24 (38\%) recorded highest reduction. According to Ratnakumar and Vadez, (2011) the seed weight reduced significantly under moisture stress and lowest seed weight was in ICGS76 and highest was in 175 and 233 groundnut genotypes. 
ANOVA revealed that 100 seed weight was highly significant $(p<0.01)$ for genotypes and moisture levels and significant $(p<0.05)$ for genotype $\times$ moisture levels interaction. Moisture stress has less impact on 100 seed weight in Dharani, Narayani and Abhaya whereas higher reduction in Greeshma (20.45\%) and JL-24 (17.7\%). Genotypic variability for 100 seed weight due to moisture stress was observed in groundnut genotypes and 100 seed weight of Tainan 9 and ICGV 98324 was higher (Vorasoot et al., 2003).

Harvest Index (HI) reduced under moisture stress and it was highly significant $(p<0.01)$ for genotypes, moisture levels and their interaction. Under control conditions HI was higher in Dharani (38.5\%) and Greeshma (34.5\%) whereas with moisture stress in Dharani (33.9\%) and Abhaya (32\%). Under control and stress conditions the genotype Dharani has moderate biomass and higher seed yield resulted better HI values, where as with moisture stress with lower seed yield and increased biomass of ICGV 91114 lead to lower HI. Shinde et al. (2010a) also reported that HI decreased with moisture stress in groundnut genotypes. Shelling \% was highly significant $(p<0.01)$ for moisture levels and significant $(p<0.05)$ for genotypes $\times$ moisture levels. The shelling $\%$ improved in Narayani and Abhaya with moisture stress though they recorded reduction in pod number. The genotype Dharani recorded highest shelling \% under both control (74.1\%) and stress $(72.7 \%)$ conditions revealing its ability to cope up with stress for seed filling also. Genotypic variability of shelling \% under moisture stress was reported by Raja Babu et al. (2010) and it was high in VG-15 and CO-1 and very poor in IGC 1697 and CGC 4018. Moisture stress influences yield by reducing $\mathrm{pod} / \mathrm{seed}$ numbers either by influencing the assimilation at the time of flowering or directly influencing pollen or ovule function. This further leads to decrease in seed-set and seed filling there by lower the number or size of the seeds resulting reduction in yields (Prasad and Staggenborg, 2008).

\subsection{Impact of moisture stress on biomass and its allocation at harvest}

At harvest, the total biomass, reproductive biomass were highly significant $(p<0.01)$ for genotypes and moisture stress and their interaction where as vegetative biomass was highly significant $(p<0.01)$ for genotypes and genotype $\times$ moisture level and significant $(p<0.05)$ for moisture levels (Table 4). Moisture stress significantly reduced vegetative $(10 \%)$, reproductive biomass $(54.7 \%)$ of all genotypes where as total biomass reduced by $31 \%$, indicating that moisture stress during flowering stage had significant influence on reproductive biomass there by reducing seed yield. The imposition of moisture stress triggered higher vegetative biomass production of ICGV 91114 however its reproductive biomass was reduced. The reproductive biomass of JL-24 was drastically reduced with moisture stress and it could be due to heavy reduction in leaf area during moisture stress and its lower recovery capacity even after stress release. The genotype Dharani recorded highest seed yield under both moisture levels and it also demonstrated lowest reduction of both vegetative and reproductive biomass with moisture stress (Table 5). Similar reproductive response patterns were reported in bambara groundnut genotypes (Laary et al., 2012) and biomass allocation traits were significantly affected by soil moisture stress and there is a variation of vegetative and reproductive biomass allocation (Huang et al., 2013). Allocation of biomass at harvest to pod and stem was highly significant $(p<0.01)$ for genotypes and moisture levels and their interaction; allocation to leaf was highly significant $(p<0.01)$ for genotypes, moisture levels and significant $(p<0.05)$ for their interaction; allocation of biomass to root was highly significant $(p<0.01)$ for moisture levels, genotype $\times$ moisture levels and significant $(p<0.05)$ for genotypes. Improved partitioning of biomass to vegetative parts under moisture stress was observed and the major increase was with roots (49\%) and leaves (40\%) whereas reduced allocation was with pods and it differed with genotypes (Table 5). Under moistures stress conditions, total biomass and their components will reduce (Li et al., 2009) and the strategy adapted by plant is to allocate more biomass to the root and leaf rather than to reproductive organ (Huang et al., 2013).

\subsection{Correlation coefficient analysis}

Correlation coefficient analysis of biochemical, growth, biomass and yield parameters of groundnut of control and moisture stress conditions were presented in Table 6 and 7 . Under control conditions seed yield had significant positive correlation with pod number $(p<0.05)$, pod weight and seed number $(p<0.01)$. The total biomass had positive correlation with POD, pod number, pod weight, vegetative biomass and reproductive biomass $(p<0.01)$ and seed number $(p<0.05)$. Under moisture stress conditions, seed yield had positive correlation with SOD, POD, leaf area, leaf dry weight $(p<0.05)$, pod weight, seed number, 100 seed weight and shelling \% $(p<0.01)$ whereas total biomass is positively correlated with pod number and vegetative biomass $(p<0.01)$. This analysis clearly indicating that the genotype with better vegetative growth was able to produce sufficient number of pods which is crucial to maintain total biomass under moisture stress conditions. Similarly, the seed yield under control condition was influenced by seed number and pod weight, while sustaining higher antioxidant enzyme activity with better leaf characters under moisture stress condition are crucial under 


\begin{tabular}{|c|c|c|c|c|c|c|c|c|}
\hline \multirow[b]{2}{*}{ Genotypes } & \multicolumn{4}{|c|}{ Biomass $\left(\mathrm{g} \mathrm{plant}^{-1}\right)$} & \multicolumn{4}{|c|}{ Biomass allocation $(\%)$} \\
\hline & Treatment & $\begin{array}{c}\text { Vegetative } \\
\text { biomass }\end{array}$ & $\begin{array}{l}\text { Reproduc- } \\
\text { tive biomass }\end{array}$ & $\begin{array}{c}\text { Total } \\
\text { biomass }\end{array}$ & Root & Leaf & Stem & Pod \\
\hline \multirow{2}{*}{ JL-24 } & $\mathrm{CN}$ & 47.6 & 31.5 & 79.1 & 2.0 & 24.3 & 33.9 & 39.8 \\
\hline & MS & 45.3 & 12.5 & 57.8 & 2.5 & 33.0 & 42.9 & 21.6 \\
\hline \multirow[t]{2}{*}{ ICGV91114 } & $\mathrm{CN}$ & 34.0 & 23.5 & 57.4 & 1.6 & 25.7 & 31.8 & 40.8 \\
\hline & MS & 54.2 & 13.8 & 67.9 & 1.4 & 35.4 & 42.9 & 20.3 \\
\hline \multirow[t]{2}{*}{ Narayani } & $\mathrm{CN}$ & 56.1 & 40.9 & 97.0 & 0.9 & 24.1 & 32.8 & 42.2 \\
\hline & MS & 37.0 & 15.6 & 52.5 & 2.6 & 31.0 & 36.8 & 29.7 \\
\hline \multirow[t]{2}{*}{ Abhaya } & $\mathrm{CN}$ & 41.9 & 39.9 & 81.8 & 2.0 & 20.4 & 28.8 & 48.8 \\
\hline & MS & 29.4 & 17.4 & 46.8 & 2.6 & 29.2 & 31.5 & 37.2 \\
\hline \multirow[t]{2}{*}{ Dharani } & $\mathrm{CN}$ & 37.8 & 39.5 & 77.3 & 1.4 & 16.6 & 31.0 & 51.1 \\
\hline & MS & 33.3 & 21.8 & 55.1 & 1.8 & 21.2 & 37.5 & 39.5 \\
\hline \multirow[t]{2}{*}{ Greeshma } & $\mathrm{CN}$ & 24.5 & 28.4 & 52.9 & 1.7 & 16.1 & 28.4 & 53.7 \\
\hline & MS & 17.1 & 11.1 & 28.2 & 3.0 & 27.0 & 30.6 & 39.4 \\
\hline \multirow[t]{2}{*}{ SED } & $\mathrm{CN}$ & 3.4 & 2.2 & 1.5 & 0.18 & 1.6 & 1.2 & 1.8 \\
\hline & MS & 4.7 & 1.5 & 5.8 & 0.34 & 0.96 & 0.9 & 1.6 \\
\hline \multirow[t]{2}{*}{$\mathrm{CD}^{*}$} & $\mathrm{CN}$ & 7.5 & 4.9 & 3.4 & 0.4 & 3.5 & 2.6 & 4.1 \\
\hline & MS & 10.4 & 3.3 & 13.1 & 0.76 & 2.1 & 2.1 & 3.6 \\
\hline \multirow[t]{2}{*}{$\mathrm{CD}^{* *}$} & $\mathrm{CN}$ & 10.6 & 6.9 & 4.8 & 0.6 & 5 & 3.7 & 5.8 \\
\hline & MS & 14.8 & 4.7 & 18.6 & 1.1 & 3.1 & 2.8 & 5.2 \\
\hline
\end{tabular}

Table 6: Simple correlation coefficients among biochemical, growth, biomass and yield parameters at control conditions of groundnut

\begin{tabular}{|c|c|c|c|c|c|c|c|c|c|c|c|c|c|c|c|c|c|}
\hline & $\operatorname{Pr}$ & SOD & POD & LA & LDW & SDW & SLW & AGB & PN & PW & SN & SW & $100 \mathrm{SW}$ & $\mathrm{SH}$ & VB & $\mathrm{RB}$ & TB \\
\hline $\operatorname{Pr}$ & 1 & & & & & & & & & & & & & & & & \\
\hline SOD & -0.35 & 1 & & & & & & & & & & & & & & & \\
\hline POD & -0.55 & -0.33 & 1 & & & & & & & & & & & & & & \\
\hline LA & -0.24 & 0.45 & 0.05 & 1 & & & & & & & & & & & & & \\
\hline LDW & -0.25 & 0.59 & -0.16 & $0.96^{* *}$ & 1 & & & & & & & & & & & & \\
\hline SDW & -0.04 & 0.26 & 0.04 & $0.94^{* *}$ & $0.88^{* *}$ & 1 & & & & & & & & & & & \\
\hline SLW & -0.19 & 0.64 & -0.67 & 0.39 & 0.63 & 0.29 & 1 & & & & & & & & & & \\
\hline AGB & -0.16 & 0.43 & -0.07 & $0.97^{* *}$ & $0.97^{* *}$ & $0.97^{* *}$ & 0.49 & 1 & & & & & & & & & \\
\hline PN & -0.47 & -0.44 & 0.62 & -0.51 & -0.54 & -0.42 & -0.38 & -0.49 & 1 & & & & & & & & \\
\hline PW & -0.52 & -0.27 & 0.64 & -0.08 & -0.12 & 0.07 & -0.22 & -0.02 & $0.87^{* *}$ & 1 & & & & & & & \\
\hline SN & -0.40 & -0.44 & 0.49 & -0.24 & -0.25 & -0.08 & -0.15 & -0.16 & $0.90^{* *}$ & $0.94^{* *}$ & 1 & & & & & & \\
\hline SW & -0.67 & 0.00 & 0.42 & 0.12 & 0.17 & 0.19 & 0.19 & 0.20 & $0.72^{*}$ & $0.91^{* *}$ & $0.88^{* *}$ & 1 & & & & & \\
\hline 100 & -0.62 & 0.62 & 0.13 & $0.76^{*}$ & $0.82^{*}$ & $0.71^{*}$ & 0.55 & $0.79^{*}$ & -0.03 & 0.38 & 0.21 & 0.64 & 1 & & & & \\
\hline SW & & & & & & & & & & & & & & & & & \\
\hline $\mathrm{SH}$ & -0.51 & $0.66^{*}$ & -0.36 & 0.48 & $0.69^{*}$ & 0.36 & $0.93^{* *}$ & 0.55 & -0.14 & 0.07 & 0.07 & 0.47 & 0.77 & 1 & & & \\
\hline VB & -0.26 & -0.66 & $0.90^{* *}$ & -0.33 & -0.53 & -0.26 & -0.85 & -0.42 & $0.74^{*}$ & 0.61 & 0.56 & 0.29 & -0.26 & -0.63 & 1 & & \\
\hline $\mathrm{RB}$ & -0.52 & -0.27 & 0.64 & -0.08 & -0.12 & 0.07 & -0.22 & -0.02 & $0.87^{* *}$ & 1.00 & $0.94^{* *}$ & $0.91^{* *}$ & 0.38 & 0.07 & 0.61 & 1 & \\
\hline TB & -0.40 & -0.56 & $0.88^{* *}$ & -0.25 & -0.41 & -0.14 & -0.66 & -0.29 & $0.87^{* *}$ & $0.85^{* *}$ & $0.79^{*}$ & 0.60 & 0.00 & -0.39 & $0.94^{* *}$ & $0.85^{* *}$ & 1 \\
\hline
\end{tabular}

Significant at ${ }^{*} p<0.05, \stackrel{* *}{p}<<0.01$, 


\begin{tabular}{|c|c|c|c|c|c|c|c|c|c|c|c|c|c|c|c|c|c|}
\hline & $\operatorname{Pr}$ & SOD & POD & LA & LDW & SDW & SLW & AGB & PN & PW & SN & SW & $\begin{array}{l}100 \\
\text { SW }\end{array}$ & $\mathrm{SH}$ & VB & $\mathrm{RB}$ & TB \\
\hline $\operatorname{Pr}$ & 1 & & & & & & & & & & & & & & & & \\
\hline SOD & $0.92^{* *}$ & 1 & & & & & & & & & & & & & & & \\
\hline POD & 0.42 & 0.41 & 1 & & & & & & & & & & & & & & \\
\hline LA & $0.82^{*}$ & $0.76^{*}$ & 0.56 & 1 & & & & & & & & & & & & & \\
\hline LDW & $0.83^{* *}$ & $0.80^{*}$ & 0.44 & $0.99^{* *}$ & 1 & & & & & & & & & & & & \\
\hline SDW & 0.29 & -0.03 & 0.32 & 0.55 & 0.49 & 1 & & & & & & & & & & & \\
\hline SLW & 0.63 & $0.71^{*}$ & -0.21 & 0.58 & $0.70^{*}$ & 0.02 & 1 & & & & & & & & & & \\
\hline AGB & $0.75^{*}$ & 0.61 & 0.46 & $0.96^{* *}$ & $0.95^{* *}$ & $0.74^{*}$ & 0.55 & 1 & & & & & & & & & \\
\hline PN & -0.56 & -0.29 & 0.26 & -0.17 & -0.20 & -0.26 & -0.31 & -0.25 & 1 & & & & & & & & \\
\hline PW & 0.44 & 0.60 & $0.83^{* *}$ & $0.69^{*}$ & 0.64 & 0.10 & 0.17 & 0.53 & 0.47 & 1 & & & & & & & \\
\hline SN & 0.31 & 0.52 & 0.65 & $0.63^{*}$ & 0.61 & 0.08 & 0.32 & 0.50 & 0.60 & $0.92^{* *}$ & 1 & & & & & & \\
\hline SW & 0.59 & $0.71^{*}$ & $0.82^{*}$ & $0.79^{*}$ & $0.75^{*}$ & 0.18 & 0.32 & 0.64 & 0.33 & $0.97^{* *}$ & $0.93^{* *}$ & 1 & & & & & \\
\hline 100 & $0.77^{*}$ & $0.68^{*}$ & $0.86^{* *}$ & $0.88^{* *}$ & $0.81^{*}$ & 0.53 & 0.20 & $0.81^{*}$ & -0.11 & $0.78^{*}$ & 0.60 & $0.84^{* *}$ & 1 & & & & \\
\hline SW & & & & & & & & & & & & & & & & & \\
\hline SH & $0.77^{*}$ & $0.82^{*}$ & $0.67^{*}$ & $0.84^{* *}$ & $0.84^{* *}$ & 0.30 & 0.56 & $0.75^{*}$ & 0.04 & $0.79^{*}$ & $0.80^{*}$ & $0.91^{* *}$ & $0.81^{*}$ & 1 & & & \\
\hline VB & -0.78 & -0.51 & -0.09 & -0.48 & -0.48 & -0.42 & -0.34 & -0.52 & $0.93^{* *}$ & 0.12 & 0.31 & -0.02 & -0.48 & -0.26 & 1 & & \\
\hline $\mathrm{RB}$ & 0.59 & $0.71^{*}$ & $0.82^{*}$ & $0.79^{*}$ & $0.75^{*}$ & 0.18 & 0.32 & 0.64 & 0.33 & $0.97^{* *}$ & $0.93^{* *}$ & 1.00 & $0.84^{* *}$ & $0.91^{* *}$ & -0.02 & 1 & \\
\hline TB & -0.58 & -0.29 & 0.14 & -0.23 & -0.25 & -0.36 & -0.24 & -0.32 & $0.99^{* *}$ & 0.39 & 0.57 & 0.27 & -0.22 & 0.01 & $0.96^{* *}$ & 0.27 & 1 \\
\hline
\end{tabular}

Significant at ${ }^{*} p<0.05 ; * p<0.01$

moisture stress condition. Vijayalakshmi et al. (2012) observed that higher leaf area played important role in maintenance of total biomass and yield under moisture stress in pearl millet.

\section{Conclusion}

Higher antioxidant enzyme activity along with better leaf characters were identified as moisture stress tolerance traits of groundnut genotype. The superior performance of genotype Dharani at both moisture levels in terms of yield could be due to better pod number, 100 seed weight. The less impact of moisture stress on these traits could be due to higher activity of antioxidant enzyme activity under moisture stress condition proving it as better adaptive genotype with higher seed yield.

\section{Further Study}

Detailed research studies on expression levels of proteins/ enzymes should be focused in order to understand the expression of genes responsible for specific proteins/enzymes to cope up with moisture stress conditions in groundnut genotypes.

\section{Acknowledgement}

The authors are highly thankful to the Director, CRIDA for providing all the facilities to conduct field and lab experiments.

\section{References}

Baroowa, B., Gogoi, N., Paul, S., Sarma, B., 2012. Morphological responses of pulse (Vigna spp) crops to soil water deficit. Journal of Agricultural Sciences 57, 31-40.

Bates, L.S., Waldren, R.P., Teare, I.D., 1973. Rapid determination of free proline for water stress studies. Plant Soil 39, 205-207.

Bhandari, H., Pandey, S., Sharan, R., Naik, D., Hirway, I., Taunk, S.K., Sastri, A.S.R.A.S., 2007. Economic costs of drought and rice farmers' drought-coping mechanisms in eastern India. In: Pandey. S., Bhandari, H., Hardy, B (Eds.), Economic Costs of Drought and Rice Farmers' Coping Mechanisms: A Cross-country Comparative Analysis, 43-112.

Bhardwaj, J., Yadav, S.K., 2012. Comparative study on biochemical parameters and antioxidant enzymes in a drought tolerant and a sensitive variety of horse gram (Macrotyloma uniflorum) under drought stress. American Journal of Plant Physiology 7, 17-29.

Castillo, F.I., Penel, I., Greppin, H., 1984. Peroxidase release induced by ozone in sedum album leaves. Plant Physiology 74, 846-851.

Dhindsa, R.S., Dhindsa, P.P., Throne, T.A., 1981. Leaf 
Senescence; Correlated with increased levels of membrane permeability and lipid peroxidation and decreased Levels of superoxide dismutase and catalase. Journal of Experimental Botany 32, 93-101.

Huang, Y., Zhao, X., Zhou, D., Wang, T., Li, G., Li, Q., 2013. Biomass allocation to vegetative and reproductive organs of Chenopodium acuminatum Willd under soil and nutrient and water stress. Bangladesh Journal of Botany 42, 113-121.

John, K., Reddy, P.R., Reddy, P.H., Sudhakar, P., Reddy, N.P.E., 2011. Genetic variability for morphological, physiological, yield and yield traits in $\mathrm{F}_{2}$ populations of groundnut (Arachis hypogaea L.). International Journal of Applied Biology and Pharmaceutical technology 2, 470-481.

Laary, J.K., Ofori, K., Kumaga, F.K., 2012. The influence of soil moisture status on reproductive growth and development of bambara groundnut (Vigna subterranean (L.) Verdc) landraces in Ghana. ARPN Journal of Agricultural and Biological Science 7, 845-851.

Li, F.L., Bao, W.K., Wu, N., 2009. Effects of water stress on growth, dry matter allocation and water-use efficiency of a leguminous species, Sophora davidii. Agroforestry Systems 77, 193-201.

Lowry, O.H., Rosenbrugh, N.J., Farr, A.L., Randall, R.J., 1951. Protein measurement with the folin phenol reagent. Journal of Biological Chemistry 193, 265-75.

Madhusudhan, K.V., Sudhakar, C., 2014a. Morphological responses of a high yielding groundnut cultivar (Arachis hypogaea L. cv. K-134) under water stress. Indian Journal of Pharmaceutical and Biological Research 2, 35-38.

Madhusudhan, K.V., Sudhakar, C., 2014b. Effect of water deficit stress on growth and chlorophyll pigments in two cultivars of groundnut. Paripex- Indian Journal of Research 3, 8-9.

Naveen, P., Daniel, K. V., Subramanian, P., Kumar, P. S., 1992. Response of irrigated groundnut (Arachis hypogaea L.) to moisture stress and its management. Indian Journal of Agronomy 37, 82-85.

Prasad, P.V.V., Staggenborg, S. A., 2008. Impacts of drought and/or heat stress on physiological, developmental, growth, and yield processes of crop plants. In: Response of crops to limited water: Understanding and modeling water stress effects on plant growth processes. Advances in Agricultural Systems Modeling Series 1, 301-355.

Puangbut, D., Jogloy, S., Vorasoot, N., Akkasaeng, C., Kesmala,T., Patanothai A., 2009. Variability in yield responses of peanut (Arachis hypogaea L.) genotypes under early season drought. Asian Journal of Plant Sciences 8, 254-264.

Raja Babu, C., Karunanithi, K., Thiruvengadam1, V.,
Saravanan, S., Vaidyanathan, R., Alagesan, A., 2011. Screening groundnut genotypes for moisture stress. International Journal of Food, Agriculture and Veterinary Sciences 1, 6-9.

Ratnakumar, P., Vadez, V., 2011. Groundnut (Arachis hypogaea L.) genotypes tolerant to intermittent drought maintain a high harvest index and have small leaf canopy under stress. Functional Plant Biology 38, 1016-1023.

Reddy, T.Y., Reddy, V.R., Anbumozhi,V., 2003. Physiological responses of groundnut (Arachis hypogaea L.) to drought stress and its amelioration: a critical review. Plant Growth Regulation 41, 75-88.

Sankar, B., Jaleel, C.A., Manivannan, P., Kishore kumar, A., Somasundaram, R., Panneerselvam, R., 2007. Drought induced biochemical modifications and proline metabolism in Abelmoschus esculentus (L.) Moench. Acta Botanica Croatica 66, 43-56.

Sharada, P., Naik, G.R., 2011. Physiological and biochemical responses of groundnut genotypes to drought stress. World Journal of Science and Technology 1, 60-66.

Shinde, B.M., Limaye, A. S., Deore, G. B., Laware, S.L., 2010a. Physiological responses of groundnut (Arachis hypogaea L.) varieties to drought stress. Asian Journal of Experimental Biological Science SPL, 65-68.

Shinde, B.M., Laware, S.L., 2010b. Effect of drought stress on agronomic and yield contributing characters in groundnut (Arachis hypogaea L.). Asian Journal of Experimental Biological Science 1, 968-971.

Vanaja, M., Yadav, S.K., Archana, G., Jyothi Lakshmi, N., Ram Reddy, P.R., Vagheera, P., Abdul Razak, S.K., Maheswari, M., Venkateswarlu, B., 2011. Response of $\mathrm{C}_{4}$ (maize) and $\mathrm{C}_{3}$ (sunflower) crop plants to drought stress and enhanced carbon dioxide concentration. Plant, Soil and Environment 57(5), 207-215.

Vijayalakshmi, T., Varalaxmi, Y., Jainender, S., Yadav, S.K., Vanaja, M., 2012. Physiological and biochemical basis of water-deficit stress tolerance in pearl millet hybrid and parents. American Journal of Plant Sciences 3, 1730-1740.

Vorasoot, N., Songsri, P., Akkasaeng, C., Jogloy, S., Patanothai, A., 2003. Effect of water stress on yield and agronomic characters of peanut (Arachis hypogaea L.). Songklanakarin Journal of Science and Technology 25, 283-288.

Vurayai, R., Emongor, V., Moseki, B., 2011. Effect of water stress imposed at different growth and development stages on morphological traits and yield of bambara groundnuts (Vigna subterranean L.Verdc). American Journal of Plant Physiology 6, 17-27. 